\title{
Phenomenological Interpretation of the Experience of Nature in the Works of Le Corbusier
}

\author{
JaeYoung Lee
}

Ph.D. Candidate, Department of Territory, Society and Development, École des Hautes Etudes en Science Sociale, France

\begin{abstract}
This research seeks to evaluate the experience of nature in the architectural instruments as created by Le Corbusier, in terms of the phenomenology of corporal experience. The architecture of Le Corbusier is active in viewing the spectacular landscape of nature through frontal localization, windows, ramps, and roof gardens. His architecture has the attitude of separating from earth and opposing and viewing nature as an autonomic machine. The nature experience of Le Corbusier is largely divided into seeing from on high and seeing while walking. Considering the senses of the body and the aspects of movement responding to each situation, the experience of seeing and contemplating nature on a large scale has an abstract quality. Seeing nature as an object from afar basically limits the experience in the information of the senses and the abstraction of nature. For the concrete experience of nature, what is needed is the idea that the body takes part in the diverse sensorial worlds and is simultaneously taken in by the situation. This research also aims to reconsider the qualities of experiences of nature, based on the modernity characterized by the separation of human from nature and sprit from body.
\end{abstract}

Keywords: Le Corbusier; nature; landscape; seeing from on high; seeing while walking; phenomenology; body; sense and move; situation; experience; abstractiveness

\section{Introduction}

The use of glass and reinforced concrete in modern architecture has allowed the expansion of openings. Windows, which became free from the load of the structure, make it possible to see the exterior symbolizing nature by expanding the opening from the closed interior to the exterior. This is the architectural realization of the desire to view nature as an aesthetic object and to possess nature through the visual experience of the landscape. For this visual relationship with nature, Le Corbusier designed architectural instruments, and these instruments have been widely applied even to contemporary architecture. These architectural instruments are the window, the ramp, and the roof garden. This paper aims to evaluate the experience of nature through these instruments in terms of the phenomenological perspective of an 'embodied spirit' of Merleau-Ponty.

Phenomenology as embodied consciousness is a reflective philosophy regarding the modern dualism which separated mind and body. Modern

*Contact Author: JaeYoung Lee, Ph.D. Candidate, EHESS, Department of Territory, Society and Development, EHESS, 190-198, avenue de France, 75244 Paris cedex 13, Paris, France Tel: +33-1-4954-2525

E-mail: miryumok@hotmail.com

(Received October 10, 2012 ; accepted November 11, 2013) intellectualism based on Cartesian dualism degrades the senses to something as simple as the gathering of information and considers the mind's thinking to be absolute. Hence, phenomenology is an attempt to regain the concrete and qualitative values of sensory data, which had been reduced and made abstract. Before being a prejudged and reflected experience, it is, as in the words of Husserl, a 'back to the things themselves' philosophy. The research area which revealed the modality of perceptions which are produced by the interior body responding to exterior objects is the perceptive phenomenology of MerleauPonty. This philosophy contends that physical capacity influences our consciousness: "Consciousness is originarily not an "I think that," but rather an "I can." [...] Consciousness is being toward the thing through the intermediary of the body. A movement is learned when the body has understood it, that is, when it has incorporated it into its "world," and to move one's body is to aim at the things through it, or to allow one's body to respond to their solicitation ${ }^{1 "}$. Furthermore, this philosophy argues that the body and object are closely joined. In other words, to move the body is to respond to the request of the object and at the same time to be taken by the object. On this foundation, the detailed aspects of human perception and movement in time-space were analyzed. This phenomenological analysis is effective in modern architecture in revealing 
the problems of objectivity and the abstractness of experience and regaining the concreteness of experience.

This paper selects the architecture of Le Corbusier as the typical example of modern architecture with the installation of landscape views. From a behavioral viewpoint, the experiences obtained from his architectural instruments can be divided into seeing from on high and seeing while walking. The characteristics of these two experiences will be analyzed.

\section{Ideas and Methods for Nature in Le Corbusier 2.1 Ideas of Nature in Le Corbusier}

Le Corbusier's view of nature is reflected in his architectural works. Therefore, before discussing his works, it is necessary to discuss his views of nature. As a pioneer of modern architecture, his view of nature is faithful to the modern dualism. His earlier writings especially reveal that he basically separated human and nature in his conception of the world. Nature for him was operated by immanent law, and its appearance is chaotic ${ }^{2}$. He thought that only the rationality of humans could find and use mathematical laws (geometry), in other words order, in the essence of nature. Hence, he interpreted objects in nature via geometrical shapes such as circles, right angles, and straight lines ${ }^{3}$.

This dualistic way of thinking appears in his work as well. Especially in his earlier works he pursued essential and universal beauty through the composition of pure geometrical forms as created by human rationality. The purism in his earlier artwork is a typical example. In his late works, he synthesizes organic forms using free curves, but most of his work is based on compositions of geometrical forms. In contrast, when pursuing the beauty of nature's appearance, he opted for a spectacular landscape. Ironically, he saw beauty in the landscape he had considered chaotic.
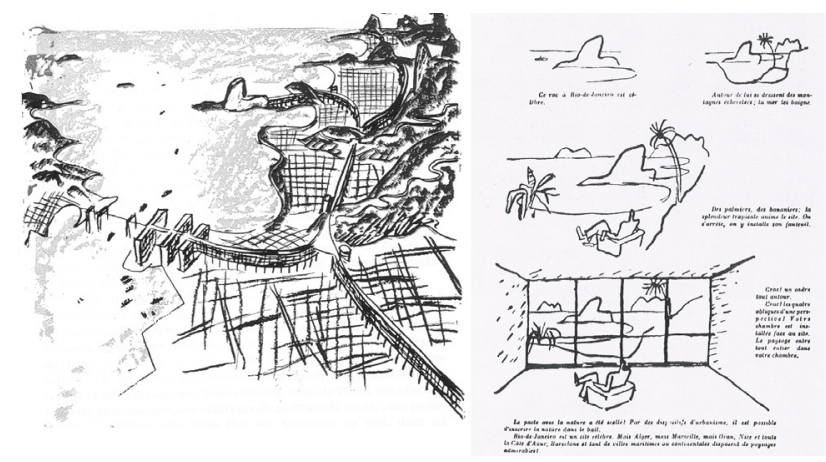

Fig.1. The Sketches for Expanding in Rio de Janeiro

For example, the sketches for expanding in Rio de Janeiro (1929) show that he plans an interior life to appreciate the primitive natural landscape through a full window in the room ${ }^{4}$. A view of the spectacular landscape is his method of pursuing nature in most of his work. Also, regarding the harmony between man- made structures and nature, he idealized the beauty of the distinct contrast between the two. He pursued harmonious beauty through the contrast of pure white geometrical artifacts and primitive nature untainted by humans. The effect was to present an image that places great emphasis on the differences between the two ${ }^{5}$.

Le Corbusier planned a few works that exemplified regionalism: Maison Mandrot (1931), Maison de Weekend (1935), and others. However, most of his architectural work is based on the geometric architecture of the modern mechanical age. In his later works, realizing organic forms by adding free curves is another evolution towards a different form of modern architecture. This organic philosophy is also a branch of modernity, as an organism refers to structural forms rather than the exterior appearance of nature. Therefore, it pursues essence. Thus, Le Corbusier's view of nature and architecture is based on the modern dualism in which immanent essence is considered to be more important.

\subsection{Views of the Landscape: Seeing from on High and Seeing while Walking}

The body's experience of viewing the landscape in Le Corbusier's architecture can be largely divided into two types: seeing from on high and seeing while walking. Within his works, there are places that resemble dark caves due to the limited openings at ground level, in contrast to the free opening to nature. However, locating a high position from which to watch the overall landscape is a major method of Le Corbusier's architecture regarding nature, and this is what is meant by seeing from on high. The sketch of la Ville radieuse is a good example of this method. The eye inside the room can see the landscape through the

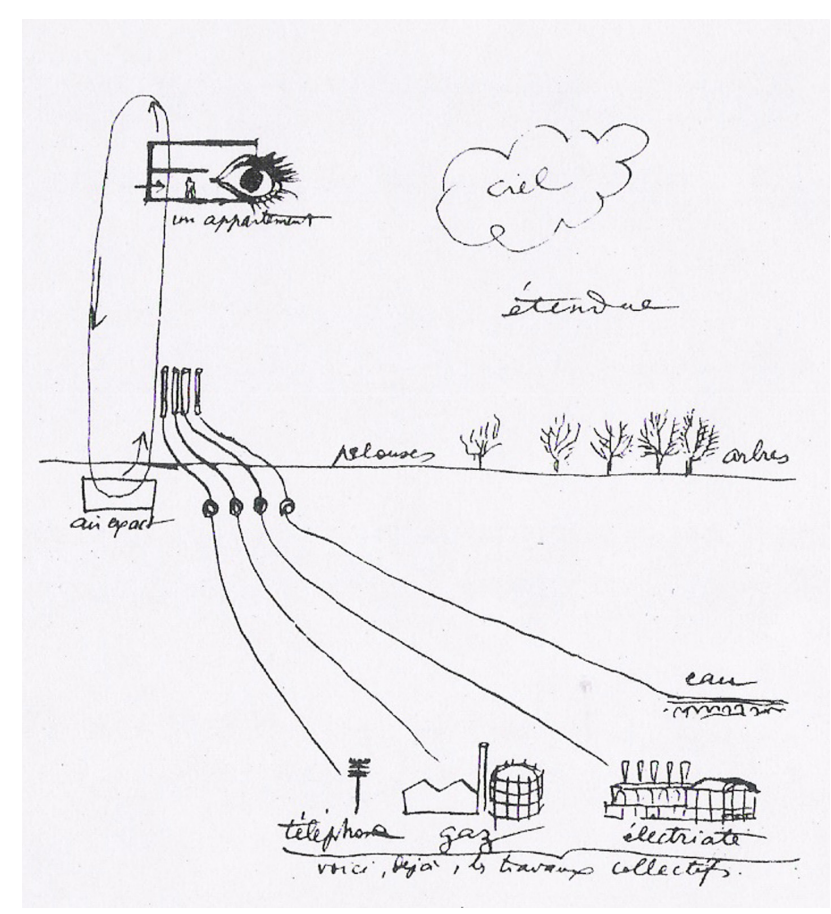

Fig.2. The Sketch of La Ville Radieuse 
window. From the inside, the outside is framed like a piece of landscape artwork. Also, from the roof garden, the mountain and the sea can be viewed. The roof garden can provide both experiences of seeing from on high and seeing while walking.

Seeing while walking is the experience of the promenade architecturale in the words of Le Corbusier. This involves viewing the surrounding landscape while walking on a ramp, while in a roof garden, or while on the ground under a building raised by pilotis. Here, what you see while moving is scenery from different angles and directions as the visual position is moved. In the Villa Savoye (1928-9), the contrast between the artificial structure and surrounding landscape can be seen in various angles while walking on the ramp which connects the second floor roof garden and the third floor solarium. In the carpenter center for the visual arts at Harvard University (1961-4), Millowner's association building (1951-4), and the church Saint Pierre de Firminy (1970-2006), the surrounding landscape can be viewed while entering the building through a ramp.
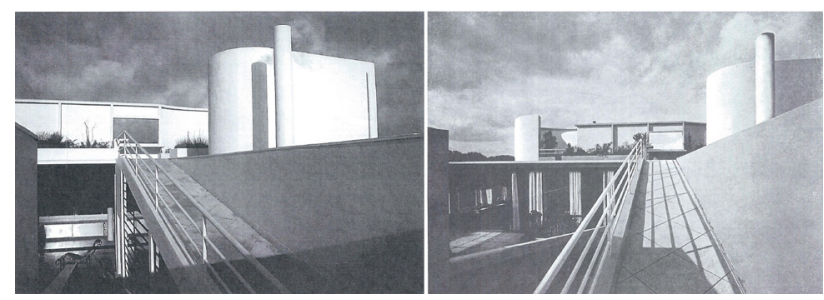

Fig.3. The Ramp of the Villa Savoye

Also, the promenade architecturale is realized at ground levels as it lifts the building with the pilotis. In the project for the League of Nations building in Geneva (1927), the surrounding lake and mountain can be viewed while walking on the ground through the space under the building raised up by the pilotis. In the same way, the house for Le Corbusier's parents (1923) allows one to view the overall landscape of the surrounding lake from various angles by walking around the building and moving to the roof garden through the stairs. The Pavillons Suisse (1930-32) and the unité d'habitation in Marseille (1946-52) also allow access to the promenade architecturale on the ground under the buildings. In this way, seeing while walking involves moving the location of the body to see the surrounding landscape, and also the synthesized image of the building, from various angles.
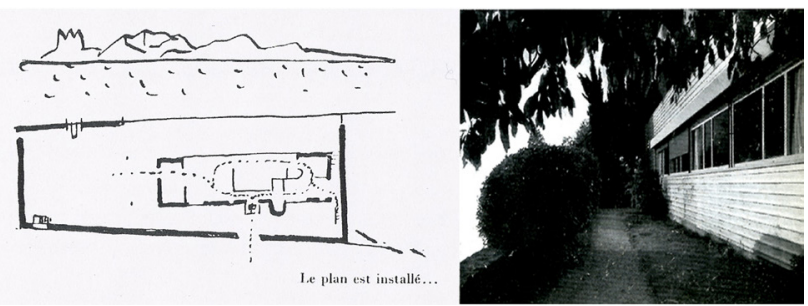

Fig.4. The House for Le Corbusier's Parents

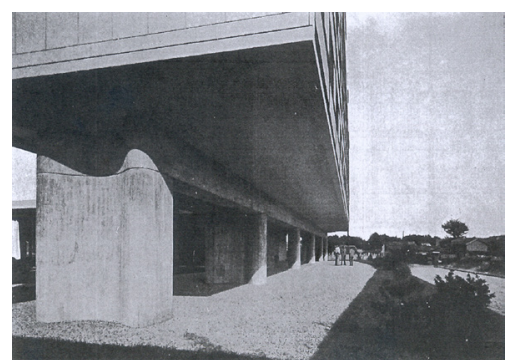

Fig.5. The Pavillons Suisse

\section{Modalities of the Experience in the Phenomenology} 3.1 Double Dimension of Being

Before focusing on the discussion regarding perception and movement, it is necessary to set the premise that human existence is an overlapping of physical aspects and social aspects. It is not possible to think only of the physical existence, nor of only social existence $^{6}$. In other words, human existence is educated through language in society, is formed by means of communication with others, and behaves with the body in each given physical and social situation. Therefore, the motive of the body to move and be attracted to objects involves the physical dimension and social dimension together. For example, a landscape is sensed by the body for its physiological dimensions, but it is also a concept of cultural and social dimensions. The beauty of a forest does not correspond to the objective physical characteristics of the forest. In other words, beauty is not felt only with the perception of its physical characteristics. With the physical characteristics as its basis, the beauty of the forest is appreciated differently according to human society and culture, and the individual which interprets $i^{7}$.

\subsection{Sense and Move in the Situation}

In the philosophy of Merleau-Ponty, perception and sensation are in the same dimension, as there is already intention involved in our perception and sensation ${ }^{8}$. The reaction of our body to a stimulus already indicates the 'sense of the situation' and its 'behavioral milieu'. Here, intention is explained in detail as the intentional threads ${ }^{10}$. The perceiving agent brings forth the intentional threads, which connect the subject and surrounding environment to perceive the surrounding environment and to move towards it. This is expressed as 'the living body raising itself toward the world ${ }^{11}$. This idea of 'being toward the world' is the most important concept of perceptional phenomenology.

The perception, sensation, and movement of existence in this world are not separated. Movement does not follow perception. It is not moving after seeing, but the seeing behavior itself is movement, and according to this movement what is seen changes. In other words, perception and movement prescribe and are prescribed by each other ${ }^{12}$. Our body can cease concrete movement in a situation and engage in abstract movement, demanding calculations and localization $^{13}$. It is in the united world where it senses 
stimuli, responds to them, behaves according to intention, and senses again new stimuli ${ }^{14}$.

Walking in a garden and appreciating nature is walking through a combined situation that includes time-space, physical, and human aspects; it is walking while perceiving, moving, contemplating, and in a situation which is changing with each moment. With every step a new perception is obtained, different thoughts can arise with new stimuli, and the walking direction may be changed. Husserl also explains the interrelationship of experience and movement as follows. When movement is complete, experience prescribes the possibility of imminent movement influenced by choice ${ }^{15}$.

\subsection{Perspectivity and Horizontality of Perception}

Merleau-Ponty said that we perceive according to the object-horizon structure at the field of the phenomenon. This is a perspective in which seeing a single object involves simultaneously understanding the relationship with its surrounding objects. "To see an object is either to have it in margins of the visual field and to be able to focus on it, or actually to respond to this solicitation by focusing on it. When I focus on it, I anchor myself in it, but this "pausing" of the gaze is but a modality of its movement: I continue within one objet the same exploration that, just a moment ago, surveyed all of them $^{16 "}$. When we are seeing an object, its appearance is different according to the position from which it is viewed. From this infinitude of different image, we understand the identity of the object. This is done by understanding the entire picture of the object and by synthesizing its relationship with the surrounding objects. Also, this perspective allows new openings and horizontal perception. The different appearance of each location allows a different synthesis for each location. Therefore, different aspects of the object can be seen. This is called the 'synthesis of horizons' or 'the presumptive synthesis ${ }^{17 "}$.

This perspective structure and horizontality of perception in space can be applied to time as well. The object we see becomes a single object that is an overall synthesis of what we saw in the past, in the present, and will see in the future. At the same time, the past understood in the present will be understood again in the future, which will become the present. Also, the distant past and the far future are open as incomplete states. This is called 'an anonymous horizon ${ }^{18}$. It has certainty only in concrete circumstances, in other words when it is adjacent.

In this way, perception is perspective, as it focuses on one within an overall relationship, and it is horizontal at the same time, as it is also perceived newly in a changing time space. Perception of modernity understands the object as an objective and fixed identity, while perception in phenomenology does not settle the object but understands it newly in each moment, location, and situation.

Merleau-Ponty contends that seeing an object is to be immersed in the object and to inhabit the object. Seeing a tree is to be attracted by the tree and to be immersed in it. This immersion into the tree is performed inside the relationship between the tree and surrounding objects, and this immersion changes according to each location and moment. In other words, it is not perceiving the identity which coincides with the physical characteristics of the tree or creating a completely subjective identity without a physical basis and situation. These together are always a new synthesis.

Along with the dimensions of perception and movement, the united situations accompanying the intention of consciousness and the context of the surroundings should be considered. Surroundings include the social meanings and the physical. Situations are a synthetic of time-space situations, physical situations, human situations, ideological situations, moral situations, etc. The body unites sensation, intelligence, sensibility, and motility ${ }^{19}$. But bodily reflexes and consciousness to a situation are complicated and delicate in the field of phenomena. Merleau-Ponty expresses this non-clearness and ambiguity in terms of hollow and fold: "But the perceived spectacle does not belong to pure being, and, since sensation is a reconstitution, it presupposes in me the sedimentations of a previous constitution; I am, as a sensing subject, full of natural powers of which I am the first to be filled with wonder. Thus I am not, to call Hegel's phase, a "hole in being," but rather a hollow, or a fold that was made and that can be unmade ${ }^{20 "}$. In this regard, experience is influenced by each situation, the sedimentations of a previous constitution and present intention.

\subsection{Space and Time Around the Body}

The modern time space is the absolute time space established by Descartes-Newton. It is a concept which adds a constant flow of absolute time to the absolute space set by the $\mathrm{X}, \mathrm{Y}$, and $\mathrm{Z}$ axes. The time space is introduced first and then the object exists in the time space. This concept is objective and definite. However, in phenomenology, the time space is considered to be relative to one's personal perspective. Heidegger said that the time space can be relative according to the ascription of meaning by a human (Dasein). This relative space concept is what defines the place (Ort). Also, Merleau-Ponty conceives of time and space expanding from the body. These concepts are not absolute, objective, and unchangeable concepts but are concepts that can undergo qualitative change according to existence.

Merleau-Ponty said, "we must not say that our body is in space, nor for that matter in time. It inhabits space and time ${ }^{21 "}$. Regarding space, the body is not inside space, but the space only exists after the body becomes involved. My body is given to me as long as I am alive, and in an actual situation we are viewing the exterior space centrally from the body. Therefore, 
space is a non-prescriptive horizon spread out from the body. When we shake hands, our whole body is 'drawn to and entwined' by the shaking hand, and with the hand as the apex, the situational space around the body changes. In this way, space changes according to the movement of the body. Also, time is relative in that there is fast flowing time and slow flowing time according to the situation in which we are living : "I am not in space and in time; nor do I think space and time; rather, I am of space and of time; my body fits itself to them and embraces them. (...) The space and time that I inhabit are always surrounded by indeterminate horizons that contain other points of view. The synthesis of time, like of space, is always to be started over again ${ }^{22}$." In this way, the time and space of Merleau-Ponty is qualitative and relative according to our body and situation.

\section{Characteristics of Experiences in the Works of Le Corbusier}

\subsection{Ideas of Body in Le Corbusier}

The ideas of Le Corbusier with regard to the body appear through 'Modulor'. Modulor was suggested to be 'a harmonic measure to the human scale, universally applicable to architecture and mechanics ${ }^{23}$. It is applied to the production of universal and standard products in the machine industry age. Le Corbusier applied 'the Modulor' to all of his architecture, from door handles to the height of the ceiling, for a harmonious proportion. The Modulor is a theory not in terms of perception and phenomenon but a theory of mathematical figures in the physical dimension of the body. This thought coincides with his modern dualistic view of nature. It is an example of applying the immanent law of nature microscopically to the body and to architecture to make a new creation according to the laws of nature. The Modulor is unrelated to the human perception and scene of phenomena.

\subsection{Abstractiveness of Experience in Seeing from on High}

Le Corbusier's view of the landscape has seeing from on high as a basis. This refers to seeing the overall spectacular view from a high place in the air. Nature (landscape) is spread out in front of the subject as an opposed object. Viewing the landscape is one method of experiencing nature, but the perceived nature and the perceiving subject also cannot break free from the stationary situation of a moment.

In the field of phenomena, perception and movement prescribe and are prescribed by each other. Furthermore, due to the perceptive and horizontal characteristic of perception, the indefinite aspects of objects can be confirmed at each moment from the relationship with the surroundings. To see a landscape, the body is immersed in it, and the movement of the body is attracted toward it. For example, a road towards a far mountain invites us to walk, the flowers blooming on the roadside make us smell, and a flowing stream makes us listen. Also, when we walk around on a hillside, we perceive another image of a far mountain that had been perceived before, and by contrasting near and far, the overall mountain is perceived and our location is identified. In other words, via detailed movement, we can obtain perceptions that change within the surrounding relationship. In addition, a more contingent and realistic appreciation can be developed from the changing perception. However, when seeing from on high, one is focusing on a single point of one aspect of nature. In this situation, the achievement of changing perception through the 'synthesis of horizons' while sensing and moving is impossible. Also, it is impossible to compare the small scale of nature with the large scale of nature. It's just possible to see the sensorial worlds of nature from a distance.

Thus, this experience depends only on sight. However, true experience of nature involves perception by all the senses - seeing, hearing, touching, smelling, and tasting. Dependence on sight causes overreliance on visual information about a situation, rather than enlarging the field of perception through the application of all senses, when sensing and moving bring forth 'the intentional threads' that connect us and nature. In addition, seeing from on high is thinking about space and time rather than inhabiting space and time. Hence, it is easy to make the experience abstract with pre-formulated and reflective thinking. This is a typically modern attitude: seeing and reflecting with the spirit in retreat. Therefore, seeing from on high is characterized by constancy and abstractness, as natural things like mountains, trees, leaves, grasses, and moss are made abstract by one color, green. This is what Le Corbusier meant when he said that nature is divided into three abstract elements: light, air, and green ${ }^{24}$.

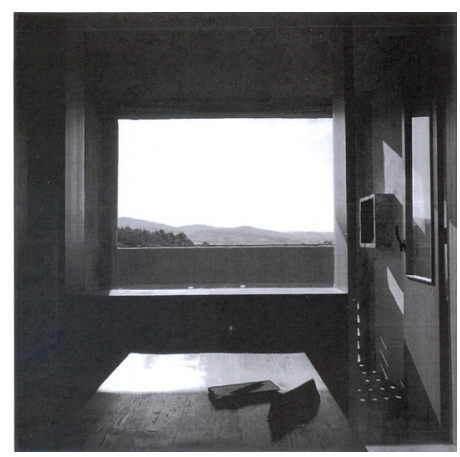

Fig.6. The View in a Room of the La Tourette

\subsection{Abstractiveness and Concreteness of Experience in Seeing while Walking}

The experience of nature achieved through seeing while walking can be more detailed than that achieved through seeing from on high. However, as the movement is performed in a high place and as it is limited to the boundary of a building, the experience of nature has an abstract quality. In the case of the unité d'habitation in Marseille, though we walk on the 
ground under the building raised by pilotis, we walk and see on its roof garden in the air. On the roof garden in the unité d'habitation in Marseille, it has both the characteristics of seeing from on high and seeing while walking. While walking on the roof garden we can see the sea and the outline of the mountain, and check the location of the sky and sun. By looking around the landscape in all directions, our own location within this nature can be identified. However, in front of the enormous scale of nature, the scale of the roof garden is a single point. We cannot walk toward the mountain on the roof garden and therefore cannot perceive the other images of the mountain. To perceive another appearance other than the stationary one, we would have to fly. Before, it was mentioned that "consciousness is 'I can' rather than 'I think"'. Because our body cannot fly, we cannot perceive concretely natural things. This aspect of seeing merely from a distance limits the 'synthesis of horizons' mode of perception. The nature experience on the roof garden of the unité d'habitation in Marseille is more detailed than from an interior room, but it is still abstract. Another typical example of this view from the air is provided by the writings and urban projects while on his voyage of Latin America. It is based on the experience of seeing while flying in an airplane ${ }^{25}$. But, though our body can fly with the instrument of a plane, it cannot fly by itself.

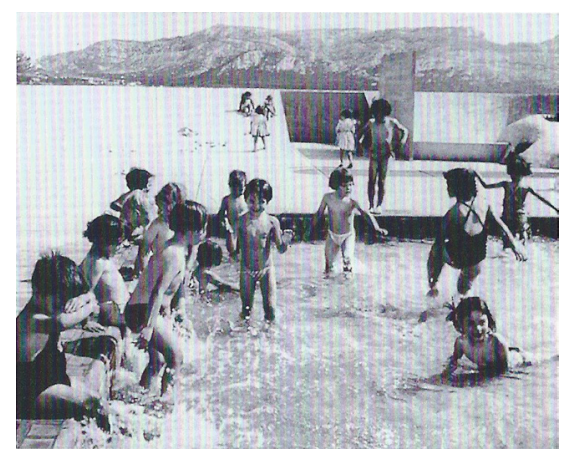

Fig.7. The Roof Garden of the unité d'habitation in Marseille

The experience of nature via seeing while walking can break away from abstractness, as it is closer to the ground and because the direction of movement can vary. In this situation, a more diverse visual sequence can be viewed. One's perception is not limited to sight. While moving, all bodily senses can experience an integrated sense of nature, as the body is immerged in the surroundings. Space and time can be made relative, opening into indeterminate horizons that contain other points of view. The space under the building of the Pavillon Suisse raised by pilotis and the space around the building of Le Corbusier's parents make possible the walk and concrete and contingent experience of nature. In the case of the Villa Savoye, a situation consisting of the surrounding natural environment and low-rise buildings can provide a more diverse appearance than situations high up in the air, although movement is circumscribed by the boundary of the ramp and the roof garden.

This promenade architecturale allows walking above or around a building, which is an architectural realization of cubist thinking in art, aiming to see different sides of an object at the same time. This is like the body turning towards a visual scene according to one's walking speed. Walking changes the location of the viewer and allows the viewer to experience the mise en scène regarding the various ways in which the building and surrounding nature appear together. This is an architectural method of combining movement and perception when forming a building.

However, in the architecture of Le Corbusier, the experience of nature largely involves abstract contemplation of nature away from the ground. His architecture is like a machine that contains images; it draws the landscape in while moving the lens to frame it, in the expression of Beatriz Colomina ${ }^{26}$.

\subsection{Different Situations and Different Contexts}

Perception and movement 'inhabit' the situation. Synthesized situations should be considered, such as the intention of the consciousness, a situational space according to body movement, and the context with the physical and social milieux.

Previously, the experience of nature while seeing from on high was characterized as abstract. However, this also differs according to the situation of the body and consciousness. When we look out at the landscape through the window, we are attracted by the landscape and feel the body's desire for nature to walk towards it. The architectural realization of this desire (intention) is the protruding balcony or the loggia. However when drinking tea by a window or sitting on an armchair in the loggia, it is easy to lead the contemplation of nature to a more spiritual dimension rather than walking towards it. In this way, there may be a difference in experience according to the intention and state of our body and consciousness. Furthermore, it is not easy to know the experience of human beings in different situations, such as various physical and social milieux; Merleau-Ponty expressed this non-clearness and ambiguity using the terms 'hollow and fold'.

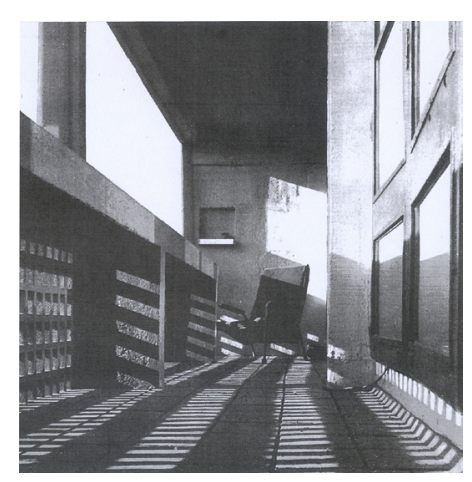

Fig.8. The Loggia of the unité d'habitation in Marseille 
Harmony with the surrounding context should also be considered. The concreteness and contingency of the experience obtained by walking up a ramp can be limited according to the situation. This phenomenon occurs when the situation on the ramp and the surrounding context is in disharmony and the assumed movement on the ramp and the perception are homogenous. The ramp in the church Saint Pierre de Firminy is a road leading towards the inside of the church. Our body and consciousness have a purpose to enter the church while walking and viewing the surroundings. Here, we have to view the front to enter, whereas to see the surrounding landscape, we need to see the side. At a certain point, the ramp leading to the church and surrounding urban landscape brings a situation which separates intention and end. The ramp does not suit the context of the surrounding landscape. As our body advances to the end on the ramp, it cannot 'draw and entwine' the timespace. In addition, these ramps induce movement of the body, but the regular speed and perception while on the ramp are homogenous. There is little space for variation or margin for difference in the density and strength of the time-space. In this space of regular movement, there is no synthesis of time, space that is continuously perceived on 'an anonymous horizon,' and diversity and ambiguity of experience in the 'hollow and fold' of human beings.

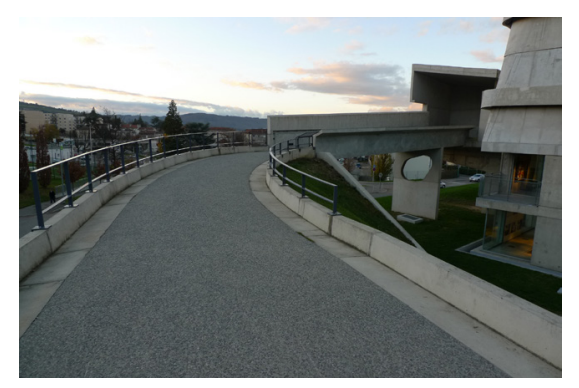

Fig.9. The Ramp of the Church Saint Pierre de Firminy

\section{Conclusion}

The architecture of Le Corbusier is based on the view of nature and body of modern dualism. Modern dualism divides the body into the spirit and the body, and divides humans and nature into a subject and an object. The body is like a sensing machine, and only the rational mind was thought to be able to see the object objectively. Our perception is subordinate to our mind, and senses are limited to collecting information about the external world. Here, the experience of nature is completely performed by the mind, and the body only senses the visual information of the landscape. This point is the basis of Le Corbusier's architecture, where nature is experienced by viewing it from a distance.

The phenomenology of Merleau-Ponty includes an 'embodied consciousness', which does not divide the mind and body. The sense of the body and perception already involves intention such that the experience is not completely charged to the mind. As it saw sensation, perception, and movement as a single overall structure in which these three elements prescribe and are prescribed by each other, the body intervenes to form consciousness. The interaction between sensation, perception, and movement means that it is responding to changing situations. As the world is not indeterminate, the world can be understood differently according to the movement of the body. Therefore, the time-space where the body resides is a relative concept which can change according to the body. As a result, the perception and movement of bodies do not hold on definitely to a situation but unite differently according to time-space situations, physical situations, and human situations.

The experience of nature in the architecture of Le Corbusier is divided into two types: seeing from on high and seeing while walking. Seeing from on high is to see the landscape in the air, i.e., away from the ground. It is experienced through an opening, a window towards a spectacular landscape. The experience depends only on vision and adheres to the large scale of the landscape and the stationary image. Its experience is so abstract because the sensorial worlds in diverse scales are seen from a distance. In contrast, seeing while walking with accompanying movement allows the experience of a more diverse visual image. Walking is induced under the pilotis and toward ramp and roof garden to view the surrounding landscape. Seeing while walking allows a perspective and horizontal experience in which sense/perception interacts with movement. However, as the location of the walk becomes higher and further away from the ground, the experience of nature becomes abstract and similar to the experience of seeing from on high. Also, the experience can differ according to the intention and state of the body and depending on the context of the surrounding milieux.

The architecture of Le Corbusier has the strong view that experience can be obtained by positioning the building in front of the object (nature) and viewing the object. The experience of nature basically depends on sight, and this experience is characterized by abstractness. With the addition of movement, different degrees of concreteness are obtained according to the situation. For the concrete experience of nature, however, it is necessary to regard diverse sensorial worlds through the application of all the senses and the synthesis of senses and bodily movement in phenomenal worlds; in this way, human beings, the physical environment, and the social milieux interact in a complex fashion. 


\section{Notes}

Merleau-Ponty, M (2012) Phenomenology of perception. London: Routledge (Originally published in 1945), pp.139-140.

2 "The man can only make use of the laws of nature. He must understand the spirit of them and make the cosmic thing the human thing, that is to say a real creation to its use. Nature is mathematical in its substance but our eye shows us merely the spectacles of disheveled appearance (often)". Author's translation of the following : : Le Corbusier (1964), La ville radieuse, Paris : Vincent, Fréal \& Cie. (Originally published in 1933), p.76.

"If we pick up a pebble polished by the sea, chosen as the roundest among millions; if we hold it with dignity, with a gesture that would set it as sculptor, like a fruit approaching a sphere, etc., This is how we aspire and what we mean by geometric". Author's translation of the following : Le Corbusier (1996) L'art décoratif d'aujourd'hui. Paris : Flammarion. (Originally published in 1925), p.113.

4 "The pact with nature has been sealed! By urban planning, it is possible to register nature in the lease. The landscape of Rio de Janeiro is admirable! [...] A frame all around! The four oblique from this perspective! The room is located opposite of the site. The landscape is brought completely into the room". Author's translation of the following: Le Corbusier and de Pierrefeu, F. (1942) La Maison des homes. Paris: Plon, p.87.

5 Fondation Le Corbusier Rencontres 031991 Paris. (2004) Le Corbusier et la nature. Paris : Fondation Le Corbusier, Editions de La Villette, pp.66-67.

$6 \quad$ Leroi-Gourhan argued in 'Le geste et la parole' that the human body developed its social, technological and symbolic functions only after its physiological functions. As in Leroi-Gourhan's argument, people live in a world where ecological, technological, and symbolic aspects are combined: Geographer Augustin Berque borrowed the concept of 'the social body' (le corps social) in 'Le geste et la parole' of archeologist Leroi-Gourhan to interpret the human body (world) in the three dimensions of physiological, technical, and symbolic. Berque, A. (2000) Ecouméne: Introduction à l'étude des milieux humains. Paris: Editions Belin, pp.96-98.

Ibid., pp.164-165.

8 "Sensation is intentional because I find in the sensible the proposition of a certain existential rhythm - abduction or adduction - and (...)", Merleau-Ponty, M. op. cit., p.221.

9 Ibid., p.81.

10 "(...) they are the center-point of the "intentional threads" that link him to the given objects. We never move our objective body, we are phenomenal body, and we do so without mystery, since it is our body as a power of various regions of the world that already rises up toward the objects to grasp and perceive them"., ibid., p.108.

11 Ibid., p.78.

2 Ibid., p.113.

13 "(...) the first (concrete movement) takes place within being o within the actual, the second(abstract movement) takes place within the possible or within non-being; the first adheres to a given background, the second itself sets up its own background"., ibid., p.114.

14 "The normal subject's body is not merely ready to be mobilized by real situations that draw it toward themselves, it can also turn away from the world, apply its activity to the stimuli that are inscribed upon its sensory surfaces, lend itself to experiments and, more generally, be situated in the virtual"., ibid., p.111.

15 Husserl E., transl. by Franck, D., Pradelle, D., and Lavigne, J.F. (1989) La Terre ne se meut pas. Paris: Les éditions de Minuit (Originally published in 1940), p.13.

Merleau-Ponty, M. op. cit., p.69-70.

Ibid., p.72.

Ibid., p.72.

19 "(...) that the life of consciousness - epistemic life, the life of desire, or perceptual life - is underpinned by an "intentional arc" that projects around us our past, our future our moral situation or rather that ensures that we are situated within all of these relationships. This intentional arc creates the unity of the senses, the unity of the senses with intelligence, and the unity of sensitivity and motricity"., Merleau-Ponty, M. op. cit., p.137.

20 Ibid., pp.222-223.

${ }^{21} \quad$ Ibid., p. 140.
$22 \quad$ Ibid., p.141.

23 Curtis, W. (2010) Le Corbusier : Ideas and Forms. London: Phaidon. (Originally published in 1986), p.163.

24 "(...) modernity has strived to submit forms of the city to the demands that came from the science of nature, such that they could be symbolized in the rhetoric of one Le Corbusier, the trinity of light, air and green. (...) naturalism of modern movement in architecture has rejected this predicate, substituting for it the fetishes of trinity: glass (Light), isolation (Air) of the building within a space of vegetation (Green)". Author's translation of the following: Berque, A. op. cit., pp.225-226.

25 "On the plane, I took my sketchbook; I drew as soon as everything became clear to me. I expressed ideas of modern urban planning. And as I was too swollen to enthusiasm, I talked to friends, explained my sketches of the airplane and here it is; I will talk about Rio". Author's translation of the following: Le Corbusier (1994) Précision: Sur un état présent de l'architecture et de l'urbanisme. Paris : ALTAMIRA (Originally published in 1930), pp.236-237.

26 Colomina, B., transl. by Brayer M.-A. (1998) La publicité du privé : de Loos à Le Corbusier. Orléan : HYX, p.237.

\section{Figure Credits}

1(left), from Le Corbusier (1994) Précision : Sur un état présent de l'architecture et de l'urbanismel 1(right), from Le Corbusier (1942) La maison des hommes/2, from Le Corbusier (1964) La ville radieusel 3(left), from Jencks C. (2000) Le Corbusier and the continual revolution in architecture, New York: Monacelli press/ 3(right), 5, from Boesiger W. (1999) Le Corbusier et Pierre Jeanneret, Oeuvre complète, Volume 2, 1929-1934/ 4, from Le Corbusier (1981) Une petite maison/ 6, from Marc Chauveau (2009) La Tourette: le cinquantenaire, 1959-2009, rencontre Le Corbusier - François Morellet, Suresnes: B. Chaveau/ 7, from Frampton K. (2001) Le Corbusier, New York: Thames \& Hudson/ 8, from Boesiger W. (1999) Le Corbusier, Oeuvre complète, Volume 5, 1946-1952, Bâle: Birkhäuser/ 9, taken by author.

\section{References}

1) Berque, A. (2000) Ecouméne: Introduction à l'étude des milieux humains. Paris: Editions Belin.

2) Boesiger, W. (1999) Le Corbusier et Pierre Jeanneret, Euvre complète, Volume 2, 1929-34. Basel : Birkhäuser. (Originally published in 1935).

3) Colomina, B., transl. by Brayer M.-A. (1998) La publicité du privé : de Loos à Le Corbusier. Orléan : HYX. (Originally published in 1994).

4) Curtis, W. (2010) Le Corbusier : Ideas and Forms. London: Phaidon. (Originally published in 1986).

5) Fondation Le Corbusier Rencontres 031991 Paris (2004) Le Corbusier et la nature. Paris : Fondation Le Corbusier, Editions de La Villette.

6) Husserl E., transl. by Franck, D., Pradelle, D., and Lavigne, J.F. (1989) La Terre ne se meut pas. Paris: Les éditions de Minuit (Originally published in 1940).

7) Le Corbusier and de Pierrefeu, F. (1942) La Maison des homes. Paris: Plon.

8) Le Corbusier (1996) L'art décoratif d'aujourd'hui. Paris : Flammarion. (Originally published in 1925).

9) Le Corbusier (1964), La ville radieuse, Paris : Vincent, Fréal \& Cie. (Originally published in 1933).

10) Le Corbusier (1994) Précision : Sur un état présent de l'architecture et de l'urbanisme. Paris : ALTAMIRA (Originally published in 1930).

11) Le Corbusier (1981) Une petite maison. Zürich: Editions d'architecture Zurich (Originally published in 1923).

12) Merleau-Ponty, M (2012) Phenomenology of perception. London: Routledge (Originally published in 1945). 